\title{
High $\mathrm{pH}$ reduces DNA damage caused by bile from patients with familial adenomatous polyposis: antacids may attenuate duodenal polyposis
}

\author{
D K Scates, S Venitt, R K S Phillips, A D Spigelman
}

Section of Molecular Carcinogenesis,

Haddow Laboratories, Institute of Cancer

Research, Royal

Cancer Hospital,

Cotswold Road,

Sutton, Surrey

D K Scates

$S$ Venitt

Polyposis Registry, St Mark's Hospital, London

R K S Phillips

A D Spigelman

Academic Surgical

Unit, St Mary's

Hospital Medical

School, Imperial

College of Science,

Technology and

Medicine, London

A D Spigelman

Correspondence to:

Mr A D Spigelman,

Academic Surgical Unit,

St Mary's Hospital Medica

School, London W2 1NY.

Accepted for publication

7 October 1994

\begin{abstract}
Patients with familial adenomatous polyposis (FAP) develop periampullary duodenal tumours, suggesting that bile contributes to their formation. The hypothesis that bile contains carcinogens has been tested by looking for DNA adducts (markers of carcinogen exposure) in the duodenum of patients with or without FAP and by determining whether bile can produce DNA adducts in vitro. Using ${ }^{32} \mathrm{P}$-postlabelling to detect adducts, there was an excess (compared with unaffected patients) of DNA adducts in the duodenum of FAP patients and an excess of DNA adducts in the small bowel of rats treated with FAP bile, while bile from FAP patients formed significantly more DNA adducts in vitro than did bile from controls. In this study it is shown that the excess of adduct labelling produced by FAP bile in vitro depends on the $\mathrm{pH}$ of the incubate. While adduct labelling at pH 6-8 did not differ significantly between bile from six FAP patients and six controls, at pH 4-5 FAP bile, but not control bile, produced a near threefold excess of adduct labelling over that at pH 6-8. Therapy that increases duodenal pH may therefore alleviate duodenal polyposis.
\end{abstract}

(Gut 1995; 36: 918-921)

Keywords: familial adenomatous polyposis, antacids, duodenal pH, DNA adducts.

Control

FAP

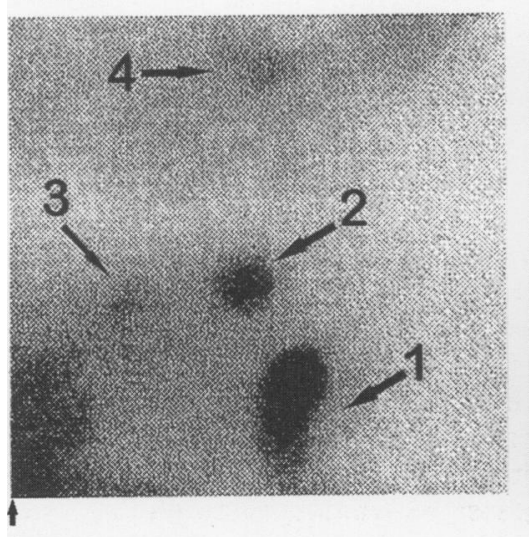

Origin

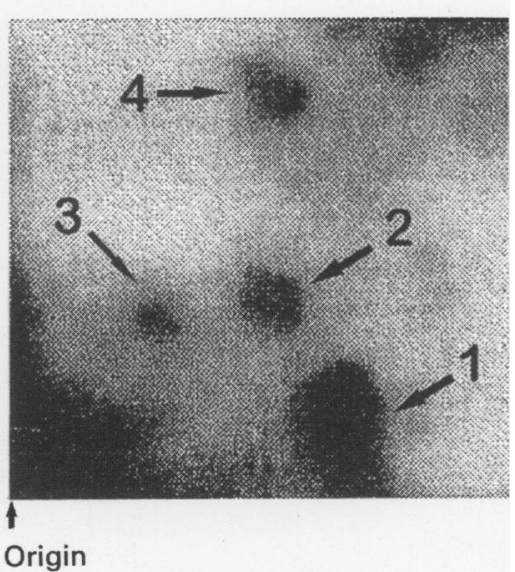

Figure 1: Autoradiographs of thin layer chromatograms (TLC) produced from

${ }^{32}$ P-postlabelling assays of salmon sperm DNA $(1 \mathrm{mg} / \mathrm{ml})$ incubated with $200 \mu \mathrm{l}$ of bile from a control patient and from a patient with familial adenomatous polyposis. Incubations were at $37^{\circ} \mathrm{C}$ for 1 hour in $10 \mathrm{mM}$ Tris adjusted to $\mathrm{pH}$. The numbered arrows indicate the four major adduct spots. 'Origin' refers to the position where the incubate was applied to the TLC plate.
Upper gastrointestinal adenomas, predominantly in the duodenum, are very common in patients suffering from the inherited autosomal dominant disease familial adenomatous polyposis (FAP). ${ }^{1}$ There is strong evidence for the adenoma-carcinoma sequence in the duodenum of these patients. ${ }^{2}$ After the colon, the duodenum is the second commonest site for malignancy in FAP patients. A recent study found a relative risk of 330 for duodenal carcinoma in FAP patients compared with the general population. ${ }^{3}$ Management of patients with duodenal polyposis remains a problem. ${ }^{4}$

Duodenal adenomas cluster around the ampulla of Vater, suggesting the involvement of bile in their development. ${ }^{1}$ In previous studies we have tested the hypothesis that bile contains carcinogens by looking for DNA adducts in the duodenal epithelium of patients with or without FAP and by determining whether bile can produce DNA adducts in vitro and in vivo. DNA adducts are chemical modifications of individual DNA bases. They are formed by the covalent binding of electrophilic carcinogens or their metabolites to DNA and are implicated in the initiation of carcinogenesis since, if left unrepaired, they can lead to mutations. ${ }^{5}$ In order to detect and quantify DNA adducts we have used ${ }^{32} \mathrm{P}$-postlabelling, a technique that enables the detection of 1 modified DNA base in $10^{9}$ normal bases. ${ }^{6}$

Using this technique, we found an excess of DNA adducts in the duodenum of FAP patients compared with controls, ${ }^{7}$ and an excess of DNA adducts in the small bowel of rats treated with FAP gall bladder bile compared with bile from control patients. ${ }^{8}$ Studies in vitro showed that FAP bile produced significantly more DNA adduct labelling than did control bile when incubated with salmon sperm DNA at the physiological $\mathrm{pH}$ of the duodenum (pH 5). ${ }^{9}$ Taken together these results indicate that bile from FAP patients contains more adduct precursors than bile from unaffected patients and suggest that bile is involved in the development of duodenal adenomas in FAP. Thus, reducing the adduct load delivered to the duodenal epithelium might decrease the risk of neoplasia. We have therefore studied how changes in the incubation conditions might affect DNA adduct formation in vitro, by varying the $\mathrm{pH}$ of the incubate. 

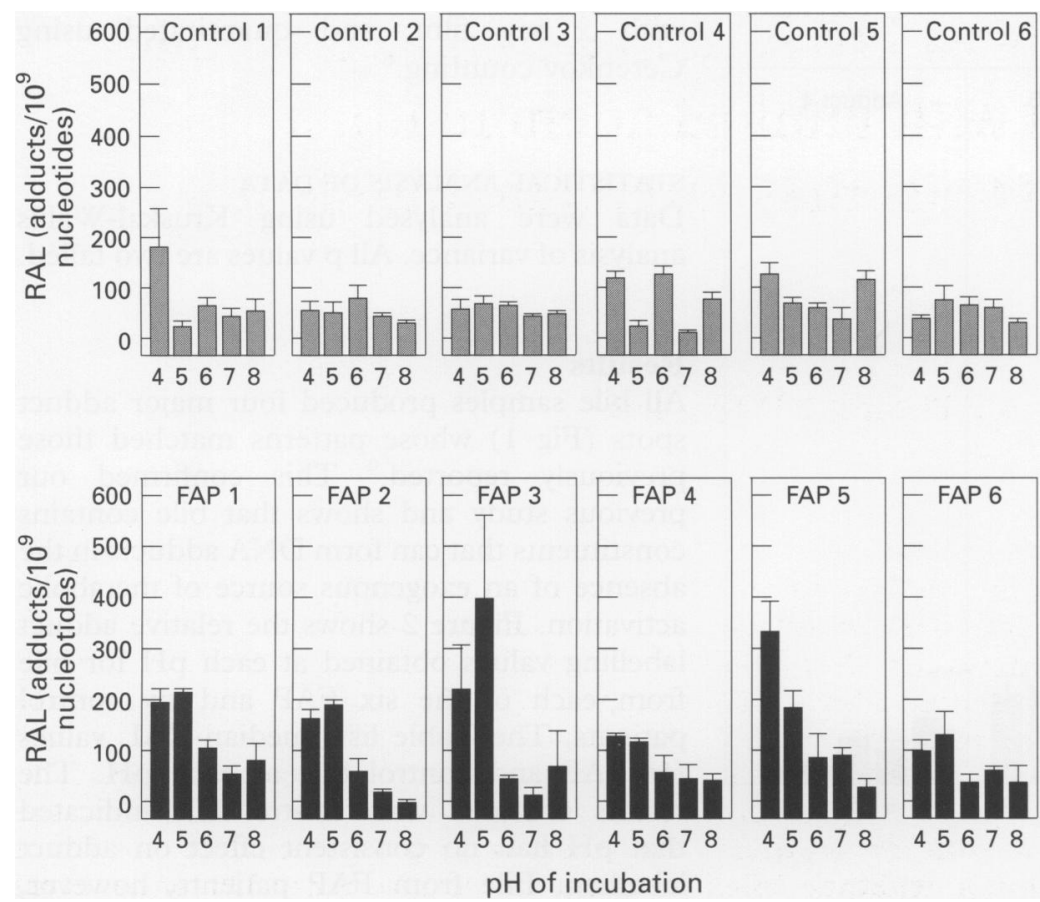

Figure 2: Results of ${ }^{32}$ P-postlabelling assays of bile from six control patients and six familial adenomatous polyposis patients. Solutions of salmon sperm DNA were made up at a concentration of $1 \mathrm{mg} / \mathrm{ml}$ in $10 \mathrm{mM}$ Tris adjusted to $\mathrm{pH}$ values $4,5,6,7$, and 8 . An aliquot of $200 \mu \mathrm{l}$ of bile from each patient was incubated with $1 \mathrm{ml}$ of salmon sperm DNA solution at each $\mathrm{pH}$ at $37^{\circ} \mathrm{C}$ for 1 hour. Each bar represents the mean and SEM of triplicate ${ }^{32} P$-postlabelling assays of DNA that was purified after incubation with bile. $R A L=$ relative adduct labelling.

\section{Methods}

COLLECTION OF BILE

Gall bladder bile was collected from FAP patients by aspiration of the gall bladder before colectomy (with the approval of the local ethical committee). Control bile was collected from non-FAP patients undergoing surgery for gall stones or from 'beating-heart' donors. Of the FAP patients (age range 24-60 years) four were male, two female; one was a smoker. There were four women and two men in the control group (age range 24-60 years). Of the six, one smoked, and two did not: the smoking status of the other three was unknown. All patients consumed a normal western diet and had not received medication that would have
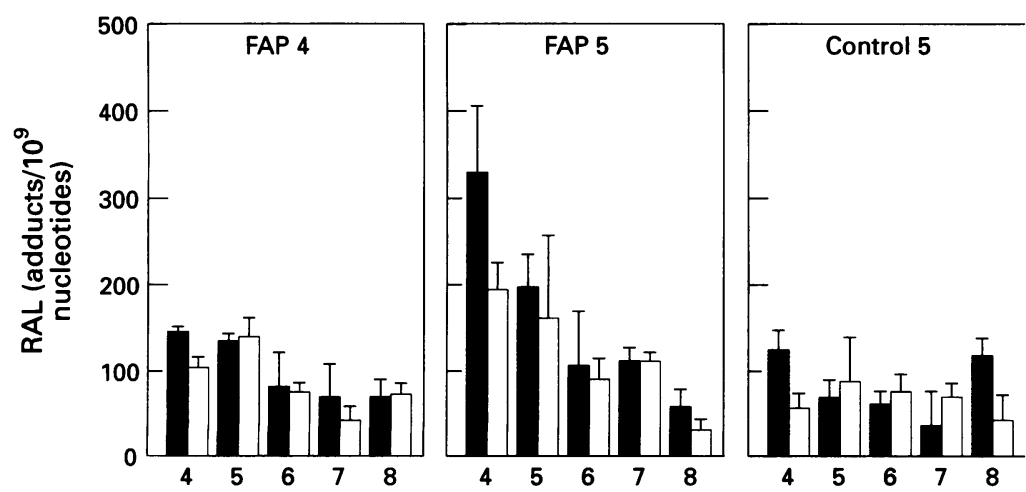

$\mathrm{pH}$ of incubation

Figure 3: Results of ${ }^{32}$ P-postlabelling assays of bile from two familial adenomatous polyposis patients and one control patient using incubations adjusted to $\mathrm{pH}$ values using Tris base $+\mathrm{HCl}$ (solid bars) or buffers (10 mM) indicated below (open bars): $\mathrm{pH} 4$ and 5 , ammonium acetate; $p H 6$ and 7, Bis-Tris; pH 8, Bicine. An aliquot of $200 \mu$ l of bile from each patient was incubated with $1 \mathrm{ml}$ of salmon sperm DNA solution $(1 \mathrm{mg} / \mathrm{ml})$ at each $\mathrm{pH}$ at $37^{\circ} \mathrm{C}$ for 1 hour. Each bar represents the mean and SEM of triplicate ${ }^{32}$ P-postlabelling assays of DNA that was purified after incubation with bile. $R A L=$ relative adduct labelling.
Adduct labelling produced by control and familial adenomatous polyposis (FAP) bile at pH 4 to 8 . Data are from three replicate postlabelling assays of $1 \mathrm{mg}$ of salmon sperm DNA incubated with $200 \mu$ l of bile from six control patients and six FAP patients at the $p H$ values shown

\begin{tabular}{lllcc}
\hline \multirow{2}{*}{$\begin{array}{l}\text { pH of } \\
\text { incubate }\end{array}$} & $\begin{array}{l}\text { Source } \\
\text { of bile }\end{array}$ & $\begin{array}{l}\text { No of } \\
\text { patients }\end{array}$ & \multicolumn{2}{c}{ RAL (adducts/109 nucleotides) } \\
\cline { 4 - 5 } & Control & 6 & 86 & $(29-174)$ \\
& Fange) \\
5 & FAP & 6 & 221 & $(122-344)$ \\
5 & Control & 6 & 54 & $(22-75)$ \\
6 & FAP & 6 & 197 & $(134-388)$ \\
7 & Control & 6 & 61 & $(58-121)$ \\
7 & FAP & 6 & 82 & $(61-125)$ \\
& Control & 6 & 44 & $(7-62)$ \\
8 & FAP & 6 & 74 & $(39-131)$ \\
& Control & 6 & 47 & $(26-113)$ \\
& FAP & 6 & 79 & $(6-106)$ \\
\hline
\end{tabular}

been likely to produce DNA adduct precursors in bile.

INCUBATION OF BILE WITH SALMON SPERM DNA IN VITRO

Solutions of salmon sperm DNA were made up to a concentration of $1 \mathrm{mg} / \mathrm{ml}$ in $10 \mathrm{mM}$ Tris base adjusted with $\mathrm{HCl}$ to $\mathrm{pH}$ values of 4, $5,6,7$, and 8 . Aliquots of $200 \mu \mathrm{l}$ of bile from six control and six FAP patients were incubated with $1 \mathrm{ml}$ of salmon sperm DNA solution at each $\mathrm{pH}$ value at $37^{\circ} \mathrm{C}$ for 1 hour. Incubations were also performed with buffered reaction mixtures, using bile from one control patient and two FAP patients. The following buffers were used, all at $10 \mathrm{mM}: \mathrm{pH} 4$ and 5, ammonium acetate (glacial acetic acid adjusted to required $\mathrm{pH}$ with ammonia); $\mathrm{pH} 6$ and 7, Bis-Tris (Sigma, Poole, Dorset, UK) adjusted to required $\mathrm{pH}$ with $\mathrm{NaOH}$ or $\mathrm{HCl}$; pH 8, Bicine (Sigma, Poole, Dorset, UK) adjusted to required $\mathrm{pH}$ with $\mathrm{HCl}$. DNA was then purified using a modification of the method devised by Gupta. ${ }^{7} 10$

\section{P-POSTLABELLING}

Relative adduct labelling (RAL, adducts per $10^{9}$ nucleotides) was determined in triplicate ${ }^{32} \mathrm{P}$-postlabelling assays of $4 \mu \mathrm{g}$ digests of DNA, using the nuclease $P_{1}$ method of postlabelling. ${ }^{911} 12$ Preliminary studies showed that this method of enrichment (removal of normal nucleotides from the digest, thereby increasing the sensitivity of the assay) produced consistently higher adduct labelling than the butanol extraction procedure, which is an alternative method for removing normal nucleotides. ${ }^{12}$ In brief, DNA was extracted and purified from the incubation mixture, and enzymically digested to 3 '-deoxynucleotides. These were incubated with an enzyme (nuclease $P_{1}$ ) to remove the $3^{\prime}$ phosphate from non-adducted nucleotides, but leaving it intact in deoxynucleotides that are chemically modified - that is, that are adducted. The resulting mixture was incubated with $\gamma-{ }^{32} \mathrm{P}$ adenosine triphosphate (ATP) and thyroxine $\left(\mathrm{T}_{4}\right)$ polynucleotide kinase which transfers the ${ }^{32} \mathrm{P}$-labelled phosphate group from ATP to the $5^{\prime}$ hydroxy group of adducted $3^{\prime}$ monophosphates, resulting in ${ }^{32} \mathrm{P}$-labelled adducted $3^{\prime}, 5^{\prime}$ bisphosphate deoxynucleotides. This mixture was separated by several cycles of 

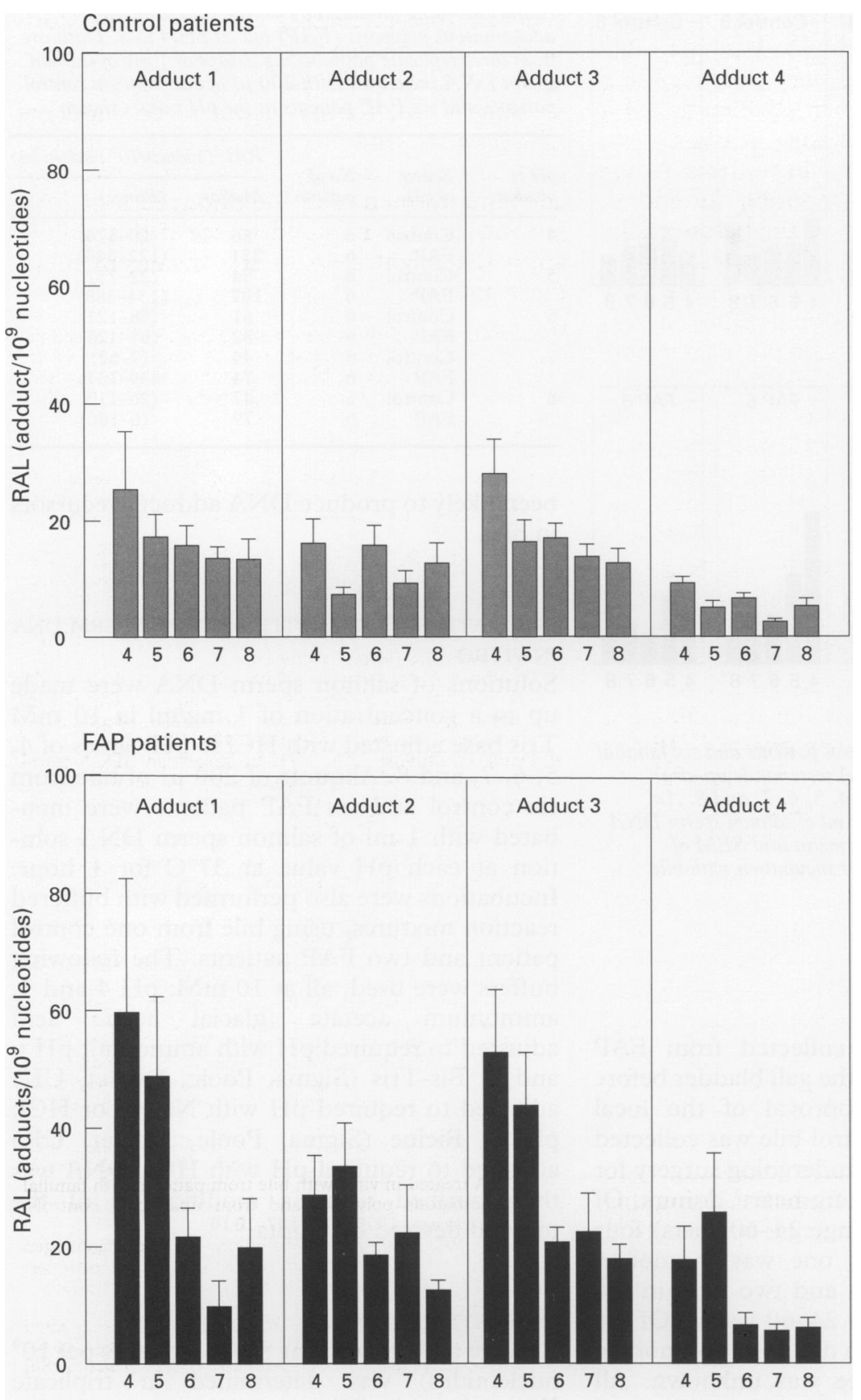

$\mathrm{pH}$ of incubation

Figure 4: Relative adduct labelling (RAL) of four major adduct spots resulting from in vitro incubation of DNA with bile as described in the text and in Figures 1 and 2. Each bar represents the mean and SEM of pooled RAL values obtained from triplicate ${ }^{32} P$-postlabelling assays of bile from six controls and six familial adenomatous polyposis patients. with $x$ ray film, and quantitated using Cerenkov counting. ${ }^{6}$

\section{STATISTICAL ANALYSIS OF DATA}

Data were analysed using Kruskal-Wallis analysis of variance. All $\mathrm{p}$ values are two tailed.

\section{Results}

All bile samples produced four major adduct spots (Fig 1) whose patterns matched those previously reported. ${ }^{9}$ This confirmed our previous study and shows that bile contains constituents that can form DNA adducts in the absence of an exogenous source of metabolic activation. Figure 2 shows the relative adduct labelling values obtained at each $\mathrm{pH}$ for bile from each of the six FAP and six control patients. The Table lists median RAL values for FAP and control bile at each $\mathrm{pH}$. The results obtained with control bile indicated that $\mathrm{pH}$ had no consistent effect on adduct labelling. Bile from FAP patients, however, produced higher levels of adduct labelling at $\mathrm{pH} 4$ and 5 than at $\mathrm{pH} 6,7$, or 8 . Statistical analysis showed the following:

(a) RAL values for FAP bile at $\mathrm{pH} 4$ and 5 were significantly higher than at $\mathrm{pH}$ 6-8 $(p=0.004)$;

(b) Taking all the data into account, adduct labelling by FAP bile at pH 4 and $\mathrm{pH} 5$ was significantly higher than for all other samples and $\mathrm{pH}$ values $(\mathrm{p}=0.00004)$;

(c) For bile from control patients, there was no significant heterogeneity of adduct labelling at different $\mathrm{pH}$ values $(\mathrm{p}=0 \cdot 168)$.

On average, adduct labelling by FAP bile was 2.7 higher at $\mathrm{pH} \mathrm{4-5}$ than at $\mathrm{pH}$ 6-8. Figure 3 shows the results (from two FAP patients and one control) of incubating DNA with bile in buffers, each of which was chosen for optimum buffering capacity at the required $\mathrm{pH}$, instead of adjusting the $\mathrm{pH}$ with Tris base and $\mathrm{HCl}$. In these assays, which were conducted in parallel, both samples of FAP bile produced significantly higher adduct labelling at $\mathrm{pH} 4$ and 5 than at $\mathrm{pH} 6-8(\mathrm{p}<0.05)$ when incubated in buffered reaction mixtures, or when incubated in Tris base adjusted with $\mathrm{HCl}$. There was no significant effect of $\mathrm{pH}$ on adduct labelling in the control sample under either of these conditions.

Levels of individual DNA adducts spots 1-4 (Fig 1) produced by control and FAP bile at different $\mathrm{pH}$ values are also presented (Fig 4). There was no significant effect of $\mathrm{pH}$ on adduct spots 1-3 produced by control bile; adduct spot 4 was slightly higher at $\mathrm{pH} 4$ than at higher $\mathrm{pH}$ values $(\mathrm{p}=0.048)$. For bile from FAP patients, adduct spots 3 and 4 were significantly higher at $\mathrm{pH} 4-5$ than at $\mathrm{pH}$ 6-8 $(p=0.0084$, adduct spot $3 ; p=0.0068$, adduct spot 4). origin. The adducts were then displaced and resolved by two further developments in high salt, high urea solvents, each development being rotated by $90^{\circ}$. Finally, residual background radioactivity was removed by another high salt development on to a wick. ${ }^{12}$ Radioactive spots were detected by autoradiography

\section{Discussion}

Our experiments show that when gall bladder bile from patients not affected by FAP was incubated with DNA at $\mathrm{pH}$ values ranging 
from 4 to 8 there were no differences in adduct labelling that could be ascribed to $\mathrm{pH}$. Bile from FAP patients, however, produced, on average, a tripling in adduct labelling at $\mathrm{pH} 4$ and 5, significantly higher than at $\mathrm{pH} 6$ to 8 , and significantly higher than in controls. As yet the components of bile responsible for adduct formation are unknown, as is the nature of the adducts that are formed. The extraordinary sensitivity of ${ }^{32} \mathrm{P}$-postlabelling (detection of 1 changed base per $10^{9}$ normal DNA bases) compared with standard chemical analytical techniques precludes rapid and facile identification of adducts detectable by ${ }^{32} \mathrm{P}$-postlabelling unless there is some prior knowledge of the agent suspected of causing them. The method of ${ }^{32} \mathbf{P}$-postlabelling used in this study detects small aromatic and bulky non-aromatic DNA adducts. ${ }^{6} 12$ The adducts produced by bile probably result from covalent binding of electrophilic compounds with DNA. Bile is the major route for the excretion of a number of xenobiotics from the body, particularly those with a molecular weight greater than 500 and which contain strongly polar groups. ${ }^{13}$ Bile is also a route of excretion for breakdown products of endogenous compounds such as steroid hormones, and, of course, contains bile acids which have long been suspected of being implicated in the aetiology of colonic cancer. The fact that a consistent pattern of DNA adducts is produced by bile from many different patients, both FAP and control, suggests that the adduct precursors are endogenous in origin rather than exogenous. Exogenous sources, for example from the diet, might be expected to produce more individual variation in the pattern of adduct formation than we have found. We have tested individual bile acids and salts for adduct formation using this method with uniformly negative results, ${ }^{14}$ suggesting that the adducts we see in DNA incubated with bile are not produced by bile acids or salts.

The fact that we cannot, at present, characterise the DNA adducts produced by bile or the precursors that form them does not disqualify our present findings from being put to practical clinical test. We showed previously that adduct labelling was significantly higher in the duodenal epithelium of FAP patients than in unaffected patients. ${ }^{6}$ Our present finding that the excess of DNA adducts produced by FAP bile can be ameliorated by raising the $\mathrm{pH}$ suggests that increasing the $\mathrm{pH}$ of the duodenum may reduce the adduct forming capabilities of bile in FAP patients and thus reduce, or slow down, the development of duodenal neoplasia. A study to determine the effect of acid lowering therapy on adduct load and adenoma formation in the duodenum of FAP patients is now required to see if this simple approach might help in the management of these patients.

We thank the consultant surgeons of St Mark's Hospital and the registrars of the Polyposis Registry of St Mark's Hospital for their help and cooperation. We gratefully acknowledge financial support from the Cancer Research Campaign of the UK (DKS, SV).

1 Spigelman AD, Williams CB, Talbot IC, Domizio P, Phillips RKS. Upper gastrointestinal cancer in patients with familial adenomatous polyposis. Lancet 1989; ii: with famil.

2 Spigelman AD, Talbot IC, Penna C, Nugent KP, Phillips RKS, Costello C, et al. The Leeds Castle Polyposis Group (Upper Gastrointestinal Committee). Evidence for adenoma-carcinoma sequence in the duodenum of patients with familial adenomatous polyposis (FAP). f Clin Pathol 1994; 47: 709-10.

3 Offerhaus GJA, Giardiello FM, Krush AJ, Booker SV, Tersmette AC, Kelley NC, Hamilton ST. The risk of upper gastrointestinal cancer in familial adenomatous polyposis. Gastroenterology 1992; 106: 1980-2.

4 Penna C, Phillips RKS, Tiret E, Spigelman AD. Surgical polypectomy of duodenal adenomas in familial adenomatous polyposis: experience of two European centres. Br f Surg 1993; 80: 1027-9.

5 Venitt S. Biological mechanisms. In: Raffle PAB, Adams PH, Baxter PJ, Lee WR, eds. Hunter's diseases of occupations. 8th ed. London: Edward Arnold, 1994: 623-53.

6 Watson WP. Post-labelling for detecting DNA damage. Mutagenesis 1987; 2: 319-31.

7 Spigelman AD, Scates DK, Venitt S, Phillips RKS. DNA adducts, detected by ${ }^{32} \mathrm{P}$-postlabelling, in the foregut of patients with familial adenomatous polyposis and in unaffected controls. Carcinogenesis 1991; 12: 1727-32.

8 Scates DK, Spigelman AD, Phillips RKS, Venitt S. DNA adducts, detected by ${ }^{32} \mathrm{P}$-postlabelling, in the intestine of rats given bile from patients with familial adenomatous rats given bile from patients with familial adenomatous polyposis and from

9 Scates DK, Spigelman AD, Nugent KP, Phillips RKS, Venitt S. DNA adducts, detected by ${ }^{32} \mathrm{P}$-postlabelling, in DNA treated in vitro with bile from patients with familial adenomatous polyposis and from unaffected controls. Carcinogenesis 1993; 14: 1107-10.

10 Gupta RC. Nonrandom binding of the carcinogen $\mathrm{N}$-hydroxy-2-acetylaminofluorene to repetitive sequences of rat liver DNA in vivo. Proc Natl Acad Sci USA 1984; 81: 6943-7.

11 Reddy MV, Randerath K. Nuclease P1-mediated enhancement of sensitivity of ${ }^{32} \mathrm{P}$-postlabelling test for structurally diverse DNA adducts. Carcinogenesis 1986; 7: 1543-51.

12 Gupta RC. ${ }^{32} \mathrm{P}$-postlabelling analysis of bulky aromatic DNA adducts. In: Phillips HD, Castegnaro $M$, Bartsch $\mathrm{H}$, eds. Postlabelling methods for detection of DNA adducts. Lyon: International Agency for Research on Cancer, 1993: 11-23.

13 Klaassen CD, Eaton DL, Cagen SZ. Hepatobiliary disposition of xenobiotics. In: Bridges JW, Chasseaud LF, eds. Progress in drug metabolism 6. London: John Wiley, 1981: $1-75$.

14 Scates DK, Sigelman AD, Venitt S. Bile acids do not form adducts when incubated with DNA in-vitro. Carcinogenesis 1994; 15: 2945-8. 